\title{
The relationship between the stock market and foreign direct investment in Croatia: evidence from VAR and cointegration analysis
}

\author{
VLADIMIR ARČABIĆ, MA* \\ TOMISLAV GLOBAN, MA* \\ IRENA RAGUŽ, MA*
}

Article**

JEL: F21, F30, F32

doi: 10.3326/fintp.37.1.4

* The authors would like to thank three anonymous reviewers for their valuable comments and suggestions to improve the quality of the paper.

** Received: March 21, 2012

Accepted: July 27, 2012

Vladimir ARČABIĆ

University of Zagreb, Faculty of Economics and Business, J. F. Kennedy 6, 10000 Zagreb, Croatia e-mail: varcabic@efzg.hr

Tomislav GLOBAN

University of Zagreb, Faculty of Economics and Business, J. F. Kennedy 6, 10000 Zagreb, Croatia e-mail: tgloban@efzg.hr

Irena RAGUŽ

University of Zagreb, Faculty of Economics and Business, J. F. Kennedy 6, 10000 Zagreb, Croatia e-mail: iraguz@efzg.hr 


\section{Abstract}

The aim of this paper is to investigate the existence and characteristics of both the long-and short-term relationships between FDI and the stock market in Croatia. The main hypothesis is that, in the long run, trends in FDI should determine the movement of the stock market through the channel of economic growth. However, in the short run, upward movement on the stock market positively affects Croatian FDI stock, as events on the stock market signalize the vitality and investment climate of the domestic market to foreign investors. The long-term connection is tested by two cointegration approaches; the results of both models suggest the absence of a long-term relationship among observed variables, which may be explained by the lack of connection between FDI and economic growth in Croatia. The short-run relationship is investigated by a two-variable VAR model, and the results obtained are consistent with the theoretical assumptions, as the stock market did prove to be an important short-term determinant of FDI in Croatia.

Keywords: VAR, cointegration, foreign direct investment, stock market, Croatia

\section{INTRODUCTION}

Faced with the lack of domestic capital required to achieve high growth rates, the countries of Central and Eastern Europe, including Croatia, turned to foreign sources of financing during the transition from a centrally planned to a market economy in the beginning of the 1990s. The dominant form of foreign capital inflows during this period was foreign direct investments (FDI), which, due to their characteristics, may have many positive effects on the host economy (Blomström, Lipsay and Zejan, 1992; Borensztein, De Gregorio and Lee, 1998; Bosworth and Collins, 1999; Loungani and Razin, 2001; etc.). Theoretical assumptions regarding the characteristics of FDI emphasize the stability, long-term motivation and resilience of this type of capital investment, even during financial crises (Lipsey, 2001). On the other hand, stock market and portfolio investments are characterized as short-term, speculative and, thus, prone to quick disinvestment and capital flight. In spite of these significant differences between the two types of capital flow, previous empirical research (Errunza, 1983; De Santis and Ehling, 2007; Adam and Tweneboah, 2008a, b; Yartey, 2008; Soumaré and Tchana Tchana, 2011) has proven the existence of a connection between FDI and portfolio investments. However, the underlying interlinkages and the direction of the causality still remain insufficiently clarified.

The purpose of this paper is to explore the existence and unravel the characteristics of the relationship between long-term (FDI) and short-term (stock market) investments in Croatia. The paper empirically examines the strength and the direction of the relationship between the two variables in the long run by using the Engle-Granger and Johansen cointegration methodology. In the long run, FDI should, through the transfer of know-how and technology, influence economic growth and, indirectly, capital markets. Alternative explanations of this long term 
relationship include the assumption that the presence of FDI inflows causes spillover effects on the domestic stock market and encourages policy makers to adopt market-friendly regulations, which encourage stock trading. In addition, we test for the existence of the short-term relationship between FDI stock and trading volume through the vector autoregressive (VAR) model approach. In the short run, assumed direction of the connection stems from events on capital markets which send signals regarding the domestic investment climate to foreign investors, and thus affect FDI. Hence, the direction of causality in the short run should be reversed. Therefore, the main hypothesis of the paper is that, in the long run, trends in FDI flows influence trading on the Croatian stock market, while in the short run events on the domestic stock market affect the volume of foreign direct investment in Croatia.

The rest of the paper is organized as follows. The introduction is followed by a review of the literature in which, in addition to the conclusions of prominent papers on the linkage between FDI and the stock market, the basic theoretical knowledge about the characteristics of both types of investments is presented. Also, it deals with the question of causality between FDI and stock markets. The third section describes the data and methodology used in the empirical research. The fourth section presents the findings of the empirical model, while the final section concludes the paper.

\section{LITERATURE REVIEW AND THEORETICAL ARGUMENTS}

At the beginning of the transition process, countries of Central and Eastern Europe, including Croatia, faced a situation of significant unemployment growth, high inflation and a decline in industrial production. Unable to finance the needed investments domestically due to the low levels of national savings, these countries looked to foreign capital to restructure the economy, intensify investment projects, finance growing domestic demand and sustain economic growth during the transition period. The dominant type of foreign capital inflows in that period were foreign direct investments.

FDI inflows into Croatia had an upward trend from the beginning of the transition period, but a significant rise in investment was marked only after the opening of accession negotiations with the European Union in 2005 (graph 1). Moreover, FDI has been the most important source of financing of the current account deficit in Croatia. However, the most significant amount of foreign capital has entered Croatia through the privatization process, i.e. through take-overs and recapitalizations of Croatian enterprises and banks. Such sources of financing are not sustainable in the long run (Jovančević, 2008). If the sectoral structure of foreign direct investment into Croatia is observed, it will become evident that the bulk of FDI inflows have entered non-manufacturing sectors - financial intermediation, wholesale trade, real estate business, the postal and telecommunications sector, and retail. At the beginning of 2011, the stock of investment into manufacturing sectors 
accounted for less than one fifth of total foreign direct investment into Croatia. Such a sectoral structure limited the positive effects of foreign direct investment on employment and economic growth in Croatia (Jovančević and Globan, 2011).

Differences between FDI and portfolio investments ${ }^{1}$, whose equity component is represented by investments on stock markets ${ }^{2}$, primarily result from different motivations of investors. Due to the taking of control and/or acquisition of significant influence in corporate governance, foreign direct investments are distinctly motivated and behave differently from other forms of investments. FDI inflows typically involve a long-term relationship between foreign investors and host companies, i.e. involve a long-term interest of foreign capital investors in the company (UNCTAD, 1999).

In contrast to direct investments, portfolio investors are usually not primarily interested in controlling and managing the enterprise, but rather in short-term capital gains. Accordingly, portfolio investments are characterized by frequent changes of ownership and places of investment, as well as by an anonymous relationship between the issuer and the holder of securities. Those investments are driven by investors' speculative expectations and due to their short-term character and the moral hazard that stems from it, portfolio investments are sometimes considered as unfavourable. That is, in the event of a financial crisis or negative expectations of investors, this type of capital is the first to flee the country and may cause serious disturbances at the micro and macro levels of the economy (Claessens, Dooley and Warner, 1995; Chuhan, Perez-Quiros and Popper, 1996; Rodrik and Velasco, 1999; Sarno and Taylor, 1999; etc.). Contrarily, FDI is considered more stable and secure (like "good cholesterol", according to Hausmann and Fernández-Arias, 2000) because it is, in theory, less susceptible to capital withdrawals and financial contagion. This is because the presence of large, fixed and illiquid assets, which comes with a direct investment, aggravates rapid disinvestment.

Although the volume of global capital flows has reached unprecedented levels over the past 20 years, the interrelationship and connection between FDI and portfolio investments has remained largely unclear. Despite the differences in character and motivation of the two types of investments, a relatively large number of empirical studies deals with the finding of causality and interlinkages between these two variables. Based on the empirical analysis, De Santis and Ehling (2007) conclude that the movements on the stock market are the most important determinant of FDI and portfolio transactions. The stock market affects the movement of FDI flows by producing signals that are important for corporate investment deci-

\footnotetext{
${ }^{1}$ According to International Monetary Fund classification, direct investments are investments through which the investor directly comes into the possession of capital that provides him 10 per cent or more of the voting rights in the company. On the other hand, in order for the investments to be considered as portfolio investments, the share of acquired capital in the form of securities (bonds, stocks, other securities issued by monetary or fiscal authorities, enterprises, banks, etc.) must not exceed 10 per cent of the total voting rights in the company (IMF, 2009).

${ }^{2}$ Debt component is represented by bond trading and other debt instruments.
} 
sions via Tobin's Q theory. On the other hand, foreign and domestic stock markets determine portfolio investments because "they measure the investment opportunity set and wealth effects" (De Santis and Ehling, 2007, p.5). Also, authors found that information about the company's fundamentals is revealed through direct investments, which is then utilized by portfolio investors when making investment decisions. In other words, portfolio investors follow firms' investment decisions when making their own.

Adam and Tweneboah (2008b) highlight an indirect, but strong relationship between stock markets and FDI inflows. FDI inflows are a source of technological progress and increasing employment in most developing countries, which increases the production of goods and services and, ultimately, increases GDP. Economic growth then has a positive effect on the development of stock markets and the rise of share prices. Using the cointegration method, the authors found evidence of a long-term positive relationship between FDI and stock market development in Ghana. In another paper, the same authors examined dynamic linkages between stock markets and major macroeconomic indicators, and again found a positive and significant relationship between FDI and stock market in Ghana. They explained these trends by the opening of the domestic stock market to foreigners and Ghanaian non-residents which has attracted high-rank institutional investors and indirectly has increased FDI inflows (Adam and Tweneboah, 2008a). The long-term impact of FDI inflows on the development of domestic capital market and on the increase of investors' participation in stock exchange was established earlier by Errunza (1983), while Yartey (2008) stated that FDI promotes institutional and regulatory reforms which encourage greater confidence in the domestic capital market, which further increases the variety of investors and trading volume.

Opening the domestic stock market to foreign investors may reduce the risk premium in the country and thus further attract foreign investments, as proven by Oyama (1997) from the examples of Venezuela, Jordan and Pakistan. The interdependence of movement in the stock markets and FDI flows is particularly evident in periods of investment euphoria when stock indices grow significantly and investors are more inclined to make riskier investment decisions. Nonnemberg and De Mendonça (2004) argue that the growth in capital markets in advanced countries is a powerful determinant of investment outflows from these countries to abroad, especially in recent times.

Although economic theory assumes a positive relation between FDI and economic growth (and thus indirectly between FDI and the capital market), this connection in Croatia and some other transition countries has not been empirically confirmed. Mencinger (2003) concluded that the correlation between FDI and economic growth in transition countries is negative. His findings are explained by the fact that in these countries, instead of greenfield investments, acquisitions have 
been the dominant form of FDI inflows which is why direct investment inflows have not had an impact on economic growth. Significant positive correlation between the two variables in transition countries failed to be empirically confirmed also by Šimurina (2006) and Bogdan (2009).

Soumaré and Tchana Tchana (2011) and Al Nasser and Soydemir (2010, cited in Soumaré and Tchana Tchana, 2011, pp.3-4) reach conclusions about the simultaneity and the bidirectional causal relationship between FDI and stock market development in developing countries. One of the explanations for this relationship consists of spillover effects on domestic stock markets brought by foreign direct investments, as FDI inflows increase the likelihood that the subsidiaries of multinational companies involved in direct investments will be listed on a domestic stock market. Other explanations include the assumption that the presence of FDI inflows encourages policy makers to adopt market-friendly regulations, like investor protection and quality trading regulations, which encourage the development of stock markets. Causality in the other direction is explicable by a welldeveloped stock market helping to attract foreign investors, a sign of vitality, a favourable investment climate and the openness of a country to foreign investments. This is especially true for emerging markets, whose stock markets are more developed than those in other developing countries (Desai, Foley and Hines, 2006; Soumaré and Tchana Tchana, 2011).

The existence of linkages between stock markets and FDI was also confirmed by Batten and Vo (2009) who found that FDI had a stronger positive impact on economic growth in countries with higher levels of stock market development. Capital markets can play an important role in determining the movement of cross-border mergers and acquisitions (M\&A), which constitute an important part of FDI. Chousa, Tamazian and Vadlamannati (2008) found a strong positive relationship between the development and quality of capital markets and M\&A flows in emerging economies. Empirical evidence showed that greater efficiency of domestic capital markets encourages foreign investors and attracts international M\&A.

Baker, Foley and Wurgler (2009) explore ways in which FDI flows depend on the stock market movements in host and source countries. They find that FDI is very strongly positively correlated with movements on the source-country's stock markets, but also not strongly negatively connected with the movements on the hostcountry's stock markets. They point out that this asymmetry has at least two natural explanations. One is that "multinationals may have better information about their own cost of capital than about the cost of capital or misvaluations in foreign capital markets". The other is that "an asymmetric limit on arbitrage, such as a short-sale constraint, may increase the scope for FDI as a means to exploit overvaluation relative to undervaluation" (Baker, Foley and Wurgler, 2009, p.365). Feridun, Sawhney and Jalil (2009) step back from FDI and explore the existence of a long-term relationship between stock prices and business investment decisions 
in Turkey. They prove the existence of a one-way positive causal relationship from stock prices to real business investments, while the reverse does not hold.

\section{DATA AND METHODOLOGY}

\subsection{DATA SETS}

In order to determine the relationship between stock market movements and FDI in Croatia, quarterly data on FDI stock and trade volume on the Zagreb Stock Exchange for the period 2001:Q1-2011:Q4 are used in the analysis. We opted for stock, rather than flow FDI data, since the former type is less volatile, it captures the longer-term trend in the foreign direct investment movement and is therefore more suitable for analysis. ${ }^{3}$ On the other hand, we chose trade volume series instead of stock market index, because stock market index and FDI stock series are correlated by construction. Namely, the methodology for calculating the FDI stock includes value adjustments which are performed using market prices of quoted stocks.

Graph 1 shows that variables FDI and VOLUME behaved procyclically and reached their highest points during mid-2000s, until the financial and economic crisis stopped their upward trend. The sharpest decreases in both variables happened at the end of 2008 and in early 2009 (concurrently with the bankruptcy of Lehman Brothers), when FDI and trade volume lost 30 and 70 per cent of their record-setting 2007:Q4 value, respectively.

\section{GRAPH 1}

FDI stock in Croatia and trade volume on ZSE in natural logarithms, 2001:Q1-2011:Q4

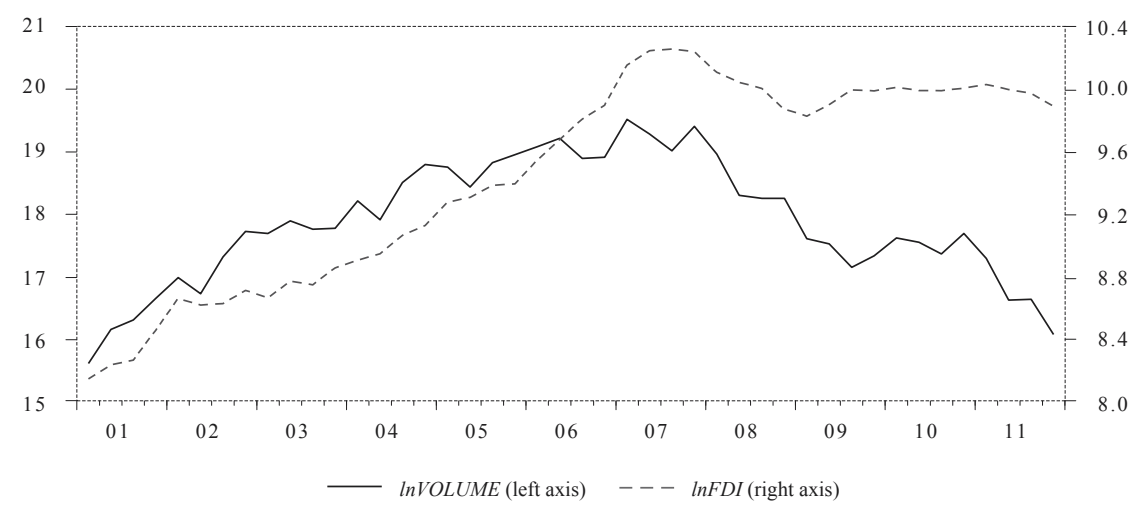

Source: CNB, ZSE.

\footnotetext{
${ }^{3}$ FDI flow series is more volatile than FDI stock, stationary in levels and it takes both positive and negative values during the observed period. As an empirical exercise, we estimated the VAR model using FDI flow series. These results are not presented in this paper due to its low performance and issues with normality of residual distribution. Both Akaike and Schwarz information criteria pointed to a model with FDI stock instead of FDI flow.
} 
FDI data are taken from the statistical database of Croatian National Bank (CNB), while the trade volume data were taken from the Zagreb Stock Exchange database. The variable VOLUME is constructed as a quarterly average of daily trade volumes. For the purpose of the analysis, both time series have been deflated by the CPI index $(2005=100)$ and expressed in natural logarithms (graph 1).

\subsection{METHODOLOGY}

As stated earlier, economic theory suggests a possible bidirectional relationship between FDI and the stock market. In the short run, developments in stock markets may affect the decision of investors whether to invest abroad, i.e. may affect the amount of FDI inflows. A growth in stock markets and positive expectations are usually an indication of market vitality, a favourable investment climate and the openness of the country to FDI (Desai, Foley and Hines, 2006; Soumaré and Tchana Tchana, 2011). However, if the long-term impact of FDI on economic growth is channelled through the process of rapid technological progress, then the causality direction is reversed, because FDI then indirectly affects stock market movements (Adam and Tweneboah, 2008b).

For the estimation of the long-term relationship between the stock market trade volume and FDI, we used Engle-Granger and Johansen cointegration approaches. Engle and Granger (1987) presented the simplest approach to cointegration testing. Components of the vector $x_{t}$ are said to be cointegrated of order $d, b, x_{t} \sim$ $C I(d, b)$ if all components of $x_{t}$ are integrated of order $d$ and there exists a vector $\beta=\left(\beta_{1}, \beta_{2}, \ldots, \beta_{n}\right)$ such that the linear combination $\beta x_{t}=\beta_{I} x_{1}+\beta_{2} x_{2}+\ldots+\beta_{n} x_{n}$ is integrated of order $(d-b)$ for $b>0$. In other words, two non-stationary I(1) variables are said to be cointegrated if the residuals of the regression equations are stationary, $I(0)$. Stationarity of the residuals is tested by conventional unit root tests such as the Augmented Dickey-Fuller test (ADF test). However, since estimates of the regression equation using the least squares method tend to minimize residuals, the critical values of the ADF test for testing the stationarity of residuals are lower than conventional tests and depend on the sample size, significance level and number of variables (MacKinnon, 1991).

Another approach in testing for cointegration was given by Johansen (1988, 1991), who described a multivariate cointegration analysis in which the vector error-correction (VEC) model is defined as follows:

$$
\Delta Z_{t}=\Gamma_{1} \Delta Z_{t-1}+\Gamma_{2} \Delta Z_{t-2}+\cdots+\Gamma_{k-1} \Delta Z_{t-k-1}+\Pi Z_{t-1}+u_{t}
$$

where $Z_{t}$ is a vector of $n$ non-stationary $I(1)$ variables, $\Gamma_{i}$ is the coefficient matrix defined as $\Gamma_{i}=\left(I-A_{1}-A_{2}-\ldots-A_{k}\right)(i=1,2, \ldots, k-1)$ representing short-run dynamics, and $\Pi$ is $n \times n$ matrix defined as $\Pi=-\left(I-A_{1}-A_{2}-\ldots-A_{k}\right)$ where $I$ is the unit matrix whose rank determines the number of cointegrating vectors. The matrix $\Pi$ contains information about the long-term relationships between variables. If $\Pi$ is of full rank, then the variables in $Z_{t}$ are stationary $I(0)$, and cointegration in this 
case is not defined. If the rank of matrix $\Pi$ equals zero, there is no cointegration relationship between the variables. However, if $\Pi$ is of reduced rank, then the model has $r \leq(n-1)$ cointegrating relationships.

In order to examine the short-term relationship between the variables in question, we use the vector autoregression (VAR) model. This model is used to evaluate the dynamics among the variables. The model is represented by the following equation:

$$
Z_{t}=\mu+\sum_{\mathrm{k}=1}^{\mathrm{p}} A_{k} Z_{t-k}+\Psi D_{t}+e_{t}
$$

where $Z_{t}$ is a vector of dependent variables, $\mu$ is a column vector of constants, $A_{k}$ is a coefficient matrix, $D_{t}$ is a vector of non-stochastic exogenous variables with the corresponding parameter matrix $\psi$, and $e_{t}$ is a column vector of innovations. Vector $D_{t}$ may contain binary variables, a trend or a seasonal component (Bahovec and Erjavec, 2009). In this paper, based on a theoretical assumption that, in the short term, events in the stock market impact FDI inflows, the Cholesky ordering of dependent variables is set as follows:

$$
Z_{t}=\left(\begin{array}{c}
\Delta \ln V O L U M E \\
\Delta \ln F D I
\end{array}\right)
$$

In a reduced form VAR, restrictions are set so that the variable $\triangle \ln F D I$ does not influence the variable $\triangle \ln V O L U M E$ in the first period, but $\triangle \ln V O L U M E$ can influence $\triangle \ln F D I$ even in the first period, which is in accordance with Cholesky ordering, where the lower triangular matrix is decomposed.

\section{RESULTS}

The analysis begins by testing the order of integration of variables. While the analysis of the VAR model is based exclusively on stationary variables, cointegration tests are performed on non-stationary variables. It is therefore very important accurately to determine the order of integration of observed variables. For this purpose an ADF test is used. ADF test results indicate that both variables (FDI and VOLUME) are integrated of order one $-I(1)$. When variables were tested in levels, we could not reject the null hypotheses of non-stationarity. However, when they were tested in first differences, non-stationarity hypotheses could be rejected at all significance levels.

\subsection{ESTIMATION OF THE LONG-TERM RELATIONSHIP BETWEEN STOCK MARKET AND FDI (COINTEGRATION APPROACH)}

The first step in the analysis is testing for the existence of a long-term relationship between the stock market, represented by trade volume, and FDI stock. In this section we examine if FDI affects stock market movements. The long run relationship and causality are tested using both Engle-Granger and Johansen cointegration approaches. 
Neither approach shows a long run relationship between observed variables. These results are not completely unexpected. As we stated in the literature review section, the main channel through which FDI can influence the stock market is economic growth. However, in case of Croatia, a number of authors have found no causal relationship between FDI and economic growth.

Following the Engle-Granger cointegration procedure, we estimated the long run equation in the first step and tested the residuals for stationarity afterwards. The following equation was estimated:

$$
\ln C R B X_{t}=\beta_{0}+\beta_{l} \ln F D I_{t}+\varepsilon_{t}
$$

However, residuals proved to be non-stationary, which implies that there is no cointegration between variables. Results of the unit root test are shown in table 1 along with critical values from MacKinnon (1991).

\section{TABLE 1}

Results of Engle-Granger and Johansen cointegration tests

Engle-Granger cointegration test (ADF test of residuals)

\begin{tabular}{|c|c|c|}
\hline $\mathrm{H}_{0}$ : no cointegration & ADF t-statistics & 5 per cent critical value ${ }^{1}$ \\
\hline$\gamma=0$ & -0.58 & -3.46 \\
\hline \multicolumn{3}{|c|}{ Johansen cointegration test results } \\
\hline \multicolumn{3}{|c|}{ Model 1: Trend and intercept assumption: intercept in CE, no intercept in VAR } \\
\hline $\mathrm{H}_{0}: \#$ of coint. vectors & $\begin{array}{c}\lambda_{\text {trace }} \text { statistics } \\
\text { (5 per cent critical value) }\end{array}$ & $\begin{array}{c}\lambda_{\max } \text { statistics } \\
\text { (5 per cent critical value) }\end{array}$ \\
\hline $\mathrm{r}=0$ & $17.44(20.26)$ & $11.70(15.89)$ \\
\hline \multicolumn{3}{|c|}{ Model 2: Trend and intercept assumption: intercept in CE and VAR } \\
\hline $\mathrm{H}_{0}$ : \# of coint. vectors & $\begin{array}{c}\lambda_{\text {trace }} \text { statistics } \\
\text { (5 per cent critical value) }\end{array}$ & $\begin{array}{c}\lambda_{\max } \text { statistics } \\
\text { (5 per cent critical value) }\end{array}$ \\
\hline $\mathrm{r}=0$ & $13.19(15.49)$ & $11.46(14.26)$ \\
\hline
\end{tabular}

${ }^{1}$ Critical values are taken from MacKinnon (1991).

The Johansen cointegration test also suggests that there are no cointegrating vectors among observed variables, which means that there is no long run relationship between them. The Johansen cointegration test was used to examine the existence of cointegration for the two forms of cointegration: (1) a model with constant in cointegration equation (CE), but without a constant or a trend in VAR and (2) a model with constant in CE and VAR without trends. Since the observed variables behaved similarly, we decided to test only the models with and without constant. Models with trend are excluded from testing, since both variables have similar movements that do not indicate the existence of a linear trend. In neither model 
can the maximum eigenvalue or trace statistics reject the null hypotheses for the number of cointegrating vectors equal to zero. Test results are shown in table $1 .{ }^{4}$

The impact of FDI on the stock market is not evident in the long run. Moreover, as theoretically argued earlier, one of the main channels through which a longterm impact of FDI inflows on the stock market takes place is the impact of FDI on economic growth. However, since there is no evidence of the existence of a long-term relationship between these variables in Croatia, the question of the validity of any long-term relationship between FDI and Croatian stock market arises. If there is no positive impact of FDI on economic growth, and, as we mentioned in the literature review, this relation has not yet been empirically proven for Croatia, then that could explain the absence of any positive effect of FDI on capital markets in the long run. However, as mentioned earlier, one should bear in mind that there are other possible explanations for the lack of a long-term relationship between the variables in question since economic growth is not the only channel through which FDI can impact the stock market in the long run.

\subsection{ESTIMATION OF THE SHORT-TERM RELATIONSHIP BETWEEN STOCK MARKET AND FDI (VAR APPROACH)}

The second part of the empirical analysis is based on estimation of the short-term relationship between the stock market and FDI in Croatia. In this part, we assume reverse causality, i.e. we assume that signals from the stock market influence investors' decisions and therefore FDI stock in the short run.

Based on the results of an ADF unit root test, vector of dependent variables $Z_{t}$ is set in accordance with equation (2) shown in the methodological review. Both variables are expressed in logarithms and are differentiated prior to the analysis, and can therefore be taken as approximations of the growth rates. In accordance with Cholesky ordering, restrictions are set so that the variable $\triangle \ln F D I$ does not influence the variable $\triangle \ln V O L U M E$ in the first period, but $\triangle \ln V O L U M E$ can influence $\triangle \ln F D I$ even in the first period. Such restrictions are in accordance with our theoretical arguments. Also, a dummy variable DUMMY (equals 1 in 2007:Q1, 0 otherwise) has been added to the model based on AIC and SIC information criteria in order to correct for the non-normality of residual distribution. A period covered with the dummy variable could be closely related to the privatization process of the Croatian oil company INA, which occurred at the end of 2006. Privatization was carried out through the initial public offering of company stocks, which boosted the trade on ZSE.

The model includes three lags, which has been determined based on the minimization of the information criteria. The stability of the model has also been tested

\footnotetext{
${ }^{4}$ We should point out several issues regarding optimal lag length of the estimated model. Namely, we based our analysis on Hannan-Quinn (HQ) information criterion. Both HQ and Schwarz information criterion (SIC) indicated one lag as optimal in a model. However, Akaike information criterion (AIC) points to either eight or four lags as optimal in a model. Choosing different number of lags changes results significantly.
} 
and the test has shown that there are no roots of the characteristic polynomial outside the unit circle; hence the model satisfies the stability condition. The diagnostic verification of the model leads to the conclusion that it satisfies all assumptions about the distribution of error terms. The tests for autocorrelation, heteroskedasticity and normality of residuals for the VAR model are presented in table 2.

\section{TABLE 2}

Diagnostic testing for violations of the assumptions of residuals distribution (p-values in parentheses)

\begin{tabular}{|c|c|c|c|}
\hline $\begin{array}{l}\text { Portmanteau test } \\
\text { for autocorrelation }\end{array}$ & $\begin{array}{l}\text { LM test for } \\
\text { autocorrelation }\end{array}$ & $\begin{array}{l}\text { Residual } \\
\text { normality test }\end{array}$ & $\begin{array}{l}\text { White heteroskedasticity } \\
\text { test (with cross terms) }\end{array}$ \\
\hline \multicolumn{4}{|c|}{ VAR model } \\
\hline Lag 1 (NA*) & Lag 1 (0.52) & Skewness (0.51) & Joint test $(0.26)$ \\
\hline Lag $4(0.08)$ & Lag 4 (0.61) & Kurtosis $(0.56)$ & \\
\hline Lag $8(0.06)$ & Lag $8(0.20)$ & Jarque-Bera (0.64) & \\
\hline Lag $12(0.25)$ & Lag $12(0.84)$ & & \\
\hline
\end{tabular}

*The test is valid only for lag lengths larger than the VAR lag order.

Table 3 presents the variance decomposition, and results point to two conclusions. First, the variance of $\triangle \ln V O L U M E$ is completely explained by its own movements (more than 90 per cent of variation). A stable structure of the variance is achieved after only three quarters, which does not change significantly even after two years (eight quarters). Such results should not be surprising. Stock trade is characterized by high volatility and persistence (autocorrelation) which is associated with expectations of investors in the stock market. The fact that $\triangle \ln V O L U M E$ explains almost 100 per cent of its own variation in the first three periods also supports these conclusions.

TABle 3

Variance decomposition of trade volume and FDI (in \%)

Variance decomposition of $\triangle \ln V O L U M E$

\begin{tabular}{|c|c|c|}
\hline Variance period (quarters) & VOLUME & FDI \\
\hline 1 & 100.0 & 0.0 \\
\hline 2 & 99.9 & 0.1 \\
\hline 4 & 93.2 & 6.8 \\
\hline 8 & 93.0 & 7.0 \\
\hline \multicolumn{3}{|c|}{ Variance decomposition of $\triangle \ln F D I$} \\
\hline Variance period (quarters) & VOLUME & FDI \\
\hline 1 & 16.1 & 83.9 \\
\hline 2 & 17.4 & 82.6 \\
\hline 4 & 30.9 & 69.1 \\
\hline 8 & 32.3 & 67.7 \\
\hline
\end{tabular}


Second, unlike the previous scenario, FDI is fairly influenced by movements in the stock market. Particularly, $\triangle \ln V O L U M E$ explains 32 per cent of $\triangle \operatorname{lnFDI}$ variation after two years. However, the stock market explains less than 25 per cent of variation in FDI in the first three quarters, but after that it becomes more important and explains around 30 and 33 per cent of variation in FDI. These results indicate that investors' decisions to invest abroad are not impulsive, because of an evident lag in variance decomposition. However, events on the stock market are an important indicator for foreign investors, since the stock market can explain around one third of the variation in FDI stock. In order to determine the nature of a reaction of FDI to shocks in the stock market, impulse response functions are analysed.

Impulse response functions confirm previous findings. From graph 2, panel (a), it is obvious that a unit shock in the stock market leads to a positive reaction in FDI in the first quarter. However, in addition to the positive reaction in the first quarter, there is a strong FDI reaction even after three and four quarters which confirms evidence from variance decomposition. Again, results confirm the contention that investors' decisions are not impulsive, but there is a lag between a shock occurrence and FDI reaction. After one year, reaction weakens and becomes insignificant. There is also a short-term impact of FDI on Croatian stock market (graph 2, panel (b)), which is statistically significant only in the fourth quarter after the occurrence of a shock. However, the response instantly fades and is not particularly strong.

\section{GRAPH 2}

Impulse response function - response to one standard deviation
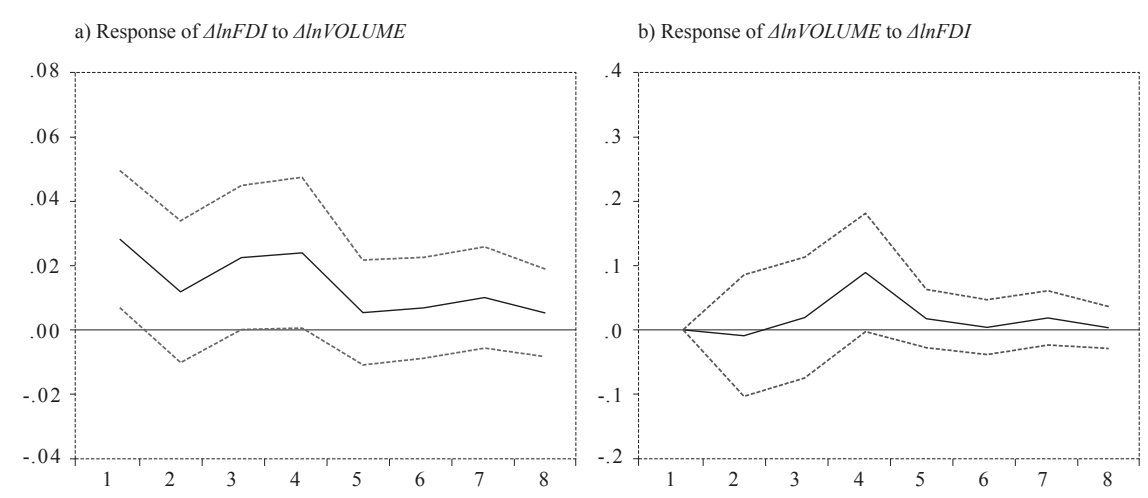

Based on the results obtained, it is plausible that there is a short-term connection between the stock market and FDI in Croatia. Stock market trade volume explains a high proportion of FDI variance (32 per cent after two years) and FDI reacts strongly and persistently to a shock from the stock market. Based on these findings it can be concluded that the domestic stock market plays an important role in informing foreign investors, i.e. that it is an important indicator of market 
vitality and the investment climate in Croatia. Through this channel, developments on the stock market are transferred to investment decisions in the short run.

\section{CONCLUSION}

Economic theory suggests bidirectional causality between foreign direct investment and stock market movements, but the direction of the relation varies in different time frames. In the short run, positive trends in stock markets can serve as an indicator of the vitality of the market, favourable investment climate and the country's openness to foreign investment. Therefore, movements in stock markets directly affect the amount of FDI in the short run. In the long run, however, the direction of causality is reversed. Namely, if FDI encourages rapid technological progress and economic growth through the transfer of know-how and technology, then it indirectly affects the growth of stock markets as well. Other explanations are based on the assumption that the presence of FDI inflows encourages policy makers to adopt market-friendly regulations and increases the confidence of investors. That further increases the number of investors and encourages the development and the volume of trade on domestic stock markets. However, the exact direction of the connection is unknown for most countries and must therefore be directly investigated.

This paper examines the case of Croatia. The basic hypothesis of the paper was that, in the short run, movement on the Croatian stock market, measured by trading volume, positively affects FDI stock in Croatia. In the long run however, the growth of FDI positively influences the stock market, i.e. trading volume. In order to investigate the long term relationship, both Engle-Granger and Johansen cointegration approaches were used, while the short term dynamics was analyzed using a two-variable VAR model. The results do not indicate a long term relationship between FDI and stock market in Croatia. However, they may not be surprising in this particular case, although they deviate from theoretically backed expectations. In fact, one of the premises for the existence of a long-term connection between FDI and the stock market is an existing significant influence of FDI on domestic economic growth. Given that previous research for Croatia and other transition countries (Mencinger, 2003; Šimurina, 2006; Bogdan, 2009) failed to confirm a significant relationship between FDI and economic growth, this could represent an obstacle to the mentioned channel of FDI impact on the Croatian stock market. However, as noted, economic growth is not the only determinant of FDI impact on the movement of the domestic stock market. Therefore, it is not easy to give a precise explanation for this finding, which remains an interesting topic for future research.

In the short run, however, stock market proved to be an important determinant of FDI. It explains about 30 per cent of variation in FDI during first eight quarters, although the initial impact is much less pronounced. Moreover, FDI significantly reacts to a shock in the stock market, but with a pronounced lag, i.e. the reaction 
is positive in the first, third and fourth quarter after the shock occurs. The results obtained are thus consistent in the short run with theoretical assumptions and prove that stock market movements are an important short-term determinant of FDI in Croatia. The observed lag can be explained by the long term character of FDI decisions, which is also in compliance with theoretical assumptions.

The main contribution of this paper is an additional step towards the clarification of the so far rather unclear relationship between FDI and the stock market in Croatia, as well as of their characteristics and determinants both in long and short run. The research proceeds from accepted theoretical assumptions, and thus represents mainly a contribution in terms of empirical research. However, the confirmation of the existence of a short-term connection and the inability to prove long-term causality between the stock market and FDI in Croatia can also be useful to policy makers and financial investors in the decision making process. 


\section{REFERENCES}

1. Adam, A. M. and Tweneboah, G., 2008a. Do macroeconomic variables play any role in the stock market movement in Ghana? MPRA Paper [online]. Available at: <http://mpra.ub.uni-muenchen.de/9301/> [Accessed 28 August 2011].

2. Adam, A. M. and Tweneboah, G., 2008b. Foreign direct investment (FDI) and stock market development: Ghana evidence. MPRA Paper [online]. Available at: <http://mpra.ub.uni-muenchen.de/11261/> [Accessed 28 August 2011].

3. Bahovec, V. and Erjavec, N., 2009. Uvod u ekonometrijsku analizu. Zagreb: Element.

4. Baker, M., Foley, C. F. and Wurgler, J., 2009. Multinationals as arbitrageurs: The effect of stock market valuations on foreign direct investment. The Review of Financial Studies, 22(1), pp. 337-369. doi: 10.1093/rfs/hhn027

5. Batten, J. A. and Vo, X. V., 2009. An analysis of the relationship between foreign direct investment and economic growth. Applied Economics, 41(13), pp. 1621-1641. doi: 10.1080/00036840701493758

6. Blomström, M., Lipsey, R. and Zejan, M., 1992. What Explains the Growth of Developing Countries? NBER Working Paper Series [online]. Available at: $<$ http://agris.fao.org/agris-search/search/display.do?f=1993/US/US93240. xml;US93208 70> [Accessed 28 August 2011].

7. Bogdan, Ž., 2009. Utjecaj FDI-ja na gospodarski rast europskih tranzicijskih zemalja, Serija članaka u nastajanju [online]. Available at: <http://web.efzg. hr/repec/pdf/ Clanak\%2009-06.pdf > [Accessed 21 December 2011].

8. Borensztein, E., De Gregorio, J. and Lee, J-W., 1998. How does foreign direct investment affect economic growth? Journal of International Economics, 45(1), pp. 115-35. doi: 10.1016/S0022-1996(97)00033-0

9. Bosworth, B. P. and Collins, S. M., 1999. Capital flows to developing economies: Implications for saving and investment. Brookings Papers on Economic Activity, 30(1), pp. 143-180. doi: 10.2307/2534664

10. Chousa, J. P., Tamazian, A. and Vadlamannati, K. C., 2008. Does growth and quality of capital markets drive foreign capital? The case of cross-border mergers and acquisitions form leading emerging economies. Turkish Economic Association Working Papers [online]. Available at: <http://www.tek.org.tr/ dosyalar/M\&A_v7.pdf $>$ [Accessed 28 August 2011].

11. Chuhan, P., Perez-Quiros, G. and Popper, H., 1996. International capital flows: do short-term investment and direct investment differ? Policy Research Working Paper Series [online]. Available at: <http://www-wds.worldbank.org/servlet/WDSContentServer/WDSP/IB/1996/10/01/000009265 3961214163507/ Rendered/PDF/multi_page.pdf $>$ [Accessed 28 August 2011].

12. Claessens, S., Dooley, M. P. and Warner, A., 1995. Portfolio capital flows: Hot or cold? World Bank Economic Review, 9(1), pp. 153-174. doi: 10.1093/ wber/9.1.153 
13. CNB - Croatian National Bank database, [online]. Available at: $<\mathrm{http}: / / \mathrm{www}$. hnb.hr/statistika/hstatistika.htm $>$ [Accessed 27 December 2011].

14. De Santis, R. A. and Ehling, P., 2007. Do international portfolio investors follow firms' foreign investment decisions? ECB Working Paper Series [online]. Available at: http://www.ecb.europa.eu/pub/pdf/scpwps/ecbwp815.pdf [Accessed 28 August 2011].

15. Desai, M. A., Foley, C. F. and Hines Jr., J. R., 2006. Capital Controls, Liberalizations, and Foreign Direct Investment. The Review of Financial Studies, 19(4), pp. 1433-1464. doi: 10.1093/rfs/hhj041

16. Engle, R. F. and Granger, C. W. J., 1987. Cointegration and error-correction: Representation, estimation and testing. Econometrica, 55(2), pp. 251-276. doi: $10.2307 / 1913236$

17. Errunza, V. R., 1983. Emerging Markets - A New Opportunity for Improving Global Portfolio Performance. Financial Analysts Journal, 39(5), pp. 51-58. doi: 10.2469/faj.v39.n5.51

18. Feridun, M., Sawhney, B. and Jalil, A., 2009. Stock market and investment in Turkey: Evidence from cointegration and causality test. Ekonomska Istraživanja/Economic Research, 22(4), pp. 17-29.

19. Hausmann, R. and Fernández-Arias, E., 2000. Foreign direct investment: Good cholesterol? RES Working Paper [online]. Available at: $<\mathrm{http}$ ://www. iadb.org/research/pub_hits.cfm?pub_id=WP-417\&pub_file_name=pubWP417.pdf $>$ [Accessed 28 August 2011].

20. IMF, 2009. Balance of Payments and International Investment Position Manual. 6th ed. Washington D.C.: International Monetary Fund.

21. Johansen, S., 1988. Statistical analysis of cointegration vectors. Journal of Economic Dynamics and Control, 12(2-3), pp. 231-254. doi: 10.1016/01651889(88)90041-3

22. Johansen, S., 1991. Estimation and hypothesis testing of cointegration vectors in Gaussian vector autoregressive models. Econometrica, 59(6), pp. 15511580. doi: $10.2307 / 2938278$

23. Jovančević, R. and Globan, T., 2011. Determinante i (ne)rezistentnost izravnih stranih ulaganja u uvjetima globalne financijske krize: primjer Hrvatske. In: A. Obadić, N. Šimurina and J. Tica, eds. Kriza: preobrazba ili propast?. Zagreb: Ekonomski fakultet Zagreb, pp. 13-30.

24. Jovančević, R., 2008. Financing of Current Account Deficit in New EU Member States and Croatia. Zbornik radova Ekonomskog fakulteta u Rijeci, 26(1), pp. 69-91.

25. Lipsey, R. E., 2001. Foreign Direct investors in three financial crises. NBER Working Papers [online]. Available at: <http://www.nber.org/papers/w8084> [Accessed 28 August 2011]. 
26. Loungani, P. and Razin, A., 2001. How Beneficial is Foreign Direct Investment for Developing Countries? Finance Development, 38(2), pp. 6-10.

27. MacKinnon, J. G., 1991. Critical values for cointegration tests. In: R.F. Engle and C.W.J. Granger, eds. Long-run economic relationships: Readings in cointegration. Oxford: Oxford University Press. Ch.13.

28. Mencinger, J., 2003. Does Foreign Investment Always Enhance Economic Growth? International Review for Social Sciences, 56(4), pp. 491-508.

29. Nonnemberg, M. B. and de Mendonça, M. J. C., 2004. The determinants of foreign direct investment in developing countries. ANPEC Proceeding of the 32nd Brazilian Economics Meeting [online]. Available at: <http://www.anpec. org.br/encontro2004/artigos/A04A061.pdf $>$ [Accessed 28 August 2011].

30. Oyama, T., 1997. Determinants of Stock Prices: The Case of Zimbabwe. IMF Working Paper, 97/117. Washington DC: International Monetary Fund.

31. Rodrik, D. and Velasco, A., 1999. Short-term capital flows. NBER Working papers, 7364 [online]. Available at: <http://www.nber.org/papers/w7364> [Accessed 28 August 2011].

32. Sarno, L. and Taylor, M. P., 1999. The Persistence of Capital Inflows and the Behaviour of Stock Prices in East Asia Emerging Markets: Some Empirical Evidence. CEPR Discussion Paper, 2150 [online]. Available at: $<$ http://wrap. warwick.ac.uk/1688/1/ WRAP_Taylor_CEPR-DP2150\%5B1\%5D.pdf $>$ [Accessed 27 December 2011].

33. Šimurina, J., 2006. Influence of FDI on Growth in Central and Eastern Europe. In: R. Jovančević and Ž. Šević, eds. Foreign Direct Investment Policies in South East Europe. Greenwich University Press - Ekonomski fakultet Zagreb.

34. Soumaré, I. and Tchana Tchana, F., 2011. Causality between FDI and financial market development: Evidence from emerging markets, MPRA Paper, 31328 [online]. Available at: <http://mpra.ub.uni-muenchen.de/31328/> [Accessed 28 August 2011].

35. UNCTAD, 1999. World Investment Report 1999. New York and Geneva: United Nations.

36. Yartey, C. A., 2008. The Determinants of Stock Market Development in Emerging Economies: Is South Africa Different? IMF Working Paper, 08/38. Washington DC: International Monetary Fund.

37. ZSE - Zagreb Stock Exchange database [online]. Available at: <http://www. zse.hr/> [Accessed 29 June 2012]. 